\title{
TABLOIDISED POLITICAL COVERAGE IN BILD-ZEITUNG ULRIKE KLEIN
}

\begin{abstract}
As modern democracies need the politically informed citizen and as politics nearly cannot be experienced and judged without the help of the mass media, there is growing concern for a tabloidisation process affecting the political news discourse within the media culture. This may be explained by both the consequences deriving from the symbiotic relationship between the media and the political

system and the commercialisation of the media system since the opening of the television market in the mid 1980s in Germany. German research analyses of the phenomenon of tabloidisation have mainly been restricted to the audiovisual media. The paper intends to give a clearer insight into the nature of "tabloidised" political coverage in the press by describing its potential extreme forms. The prototypical representative of tabloid journalism in Germany is the Bild-Zeitung.

Taking the Bild as a prototype for tabloid journalism in Germany the manifest and traditional political content of its news discourse has been analysed using framing-analytical techniques. Frames combine a pragmatical, semantical and syntactical dimension, as they serve as internalised guides for information processing and as they convey thematically consonant meanings constructed from and embodied in the keywords, metaphors, concepts, symbols and other

lexical or visual "bricks" of a given news discourse.
\end{abstract} Ulrike Klein is researcher at the Institut für Publizistik, Johannes Gutenberg-Universität Mainz. 


\section{The Present Context: Politics and the Media*}

The large majority of the population in modern democracies nearly exclusively get information about their political system and the collectively shared conceptions of the political reality through the press, radio, and television. The media system thus playing a central role in the interactions between state and society delivers both the "input" in and the "output" of the political system. "Input" means that the media are publishing facts and opinions with social relevance, serving as a "warning system" for developments within the society by indicating, at the same time, the chances for consensus about problems, persons and decisions. "Output" means that they are informing the public of decision making processes and their results in the political system. Furthermore, the mass media intensify and dense the process of communication within the political system itself representing the central information source for the exchange of thoughts between the political actors (see Marcinkowski 1996, 202-205).

As the mass media can be regarded as both transfer medium and factor of the social construction of political public opinion, and since a well-functioning democracy needs the politically informed citizen, there is growing concern for a tabloidisation process within the media culture, which can be explained by two main causes. On the one hand, the symbiotic relation between the political and the media system has raised a new type of politicians. They make use of marketing and PR-instruments and act out on the stage of the media a professional event-management, thus trying to instrumentalise the media for their image-building strategies by delivering symbolic satisfactions rather than important political content (for an extensive research overview see Schulz 1997). On the other hand tabloidisation of the political coverage is seen as a result of a growing commercialisation within the media system mainly due to the opening of the television market for private channels since the mid 80's in Germany, setting new standards and thus forcing other media to react and to develop more popular strategies to maintain their position in a competitive market. Both explanations are certainly not to be seen independent of each other.

Concerning the phenomenon of "tabloidisation" of the political coverage a series of estimations have been articulated during the last years gaining increasing popularity through frequent repetition. The current catch phrases are: a thinning out of serious political information, entertainment-orientation, sensationalism, infotainment, political symbolism instead of facts, magazinisation of news etc. (Schatz 1989, Pfetsch 1994, Krüger 1996). The notion of tabloidisation, therefore, is exchanged for or explained by similarly multi-dimensional conceptions. Analyses of the changes in form and content of the political coverage in Germany were mainly restricted to the audio-visual media (recently published: Bruns \& Marcinkowski 1997, Hesse 1994, Krüger 1996). In their corresponding bibliography Kreutzfeld \& Schmidt (1996, 296-301) enumerate approx. 100 studies, only one of those published after 1980 deals with the press (Ehmig 1991). It is true that because of its ubiquity, its potency to visualise the world of politics and the development of the dual system television deserves considerable attention, but this does not legitimise a total negligence of the press. As there is obviously a lack of research in analyses trying to explain a process of tabloidisation in the press a clarification of the concept is urgently needed: How can we measure "tabloidised" political coverage in the press? 


\section{Preliminary Thoughts on Tabloidisation of the Political Coverage in the Press}

An adaptation to tabloid style in the print media in general is possible on three levels: content, language/rhetorics and layout. The degree to which these levels can be tabloidised are variable. Therefore, we can assume a continuum ranging from extremely tabloidised to absolutely 'serious'. In order to identify the various graduations on this continuum at least one pole of the bipolarity should be known, leading us to our first question: What can be understood by (extremely) tabloidised political press coverage? In answering this question we will concentrate on content and language characteristics, and in order to identify the relevant study material we have to ask secondly which paper serves as the best representative of tabloid journalism in Germany. Starting with the latter, a real tabloid press has only developed after the second World War. The first tabloid newspaper holding a unique position in the German press market was the Bild-Zeitung. In our opinion, this paper can be viewed as the prototype of tabloid journalism in Germany, therefore, it seems justifiable to take the Bild-Zeitung as yardstick or simply as a measure for tabloidised coverage in the German press. In order to underline the prominent significance of this prototype a short sketch may be allowed.

It would not be exaggerating to say that Bild is an outstanding German newspaper for various reasons. The Bild-Zeitung is among the other 7 regional tabloids the only one in Germany with national distribution, thus, holding a monopoly in the national tabloid market. Published by the largest publishing house in Germany, the AxelSpringer-Verlag in Hamburg, which controls $20 \%$ of the daily newspaper circulation as well as over $77 \%$ of the tabloid circulation (Dewall 1997, 54) Bild is not only leader of the market in various regional markets, but also (in absolute figures) the largest newspaper in Europe with a sold circulation of 4.51 millions of copies a day (IVW, 1st quarter 1998) and approximately 11.3 millions of readers. The German Bild-Zeitung works with the most modern technical equipment possible. Articles can be changed until one o'clock in the morning; in case of extraordinary events, the general elections e. g., changes are possible until 3 a.m.. The Bild is therefore able to be the most up to date newspaper ${ }^{1}$ in Germany, the first copies are distributed at 5.30 a.m.. Ranking on place 5 behind four television channels, the Bild-Zeitung has more revenues from advertising than every other German newspaper (Sontheimer 1995, 43). A fourcoloured page of the national issue costs on average half a million DM (Stamm 1997). According to Bild, its readership reflects the structure of the population as a whole. This is only a rough interpretation. Data in Table 1 give a clearer insight.

As these data show the Bild is read in comparison to the average population (see columns 4 and 5) by more men than women, the middle age group from 40 to 59 years is overrepresented, self-employed people and those in leading positions are underrepresented, and the education level of the readers is lower than average. But although higher educated people are extremely underrepresented (8\% of the readers compared to $17 \%$ of the population as a whole) one should realise that $8 \%$ means 900.000 people, due to the large circulation and readers per issue. Thus, it would be wrong to regard the Bild-Zeitung simply as a "janitor's paper" for the "underdogs" of our society. Very often the paper is cited in the radio or television news which is certainly due to its topicality and to the fact that $22 \%$ of all German journalists read it regularly (Weischenberg, Löffelholz \& Scholl 1994, 163). 
Table 1: Readership of the Bild-Zeitung Compared to Total Population

\begin{tabular}{|c|c|c|c|c|c|}
\hline & $\begin{array}{c}\text { Total } \\
\text { population } \\
\text { (millions) }\end{array}$ & $\begin{array}{c}\text { Readers } \\
\text { per issue } \\
\text { (in \%) }\end{array}$ & $\begin{array}{l}\text { Range } \\
\text { (in \%) }\end{array}$ & $\begin{array}{c}\text { Total } \\
\text { population } \\
\text { (in \%) }\end{array}$ & $\begin{array}{l}\text { Readers } \\
\text { per issue } \\
\text { (millions) }\end{array}$ \\
\hline $\begin{array}{l}\text { German population } \\
(14 \text { years }+)\end{array}$ & 63.25 & 11.26 & 17.8 & 100 & 100 \\
\hline $\begin{array}{l}\text { Sex: } \\
\text { Men } \\
\text { Women }\end{array}$ & $\begin{array}{l}30.05 \\
33.20\end{array}$ & $\begin{array}{l}6.58 \\
4.68\end{array}$ & $\begin{array}{l}21.9 \\
14.1\end{array}$ & $\begin{array}{l}48 \\
52\end{array}$ & $\begin{array}{l}58 \\
42\end{array}$ \\
\hline $\begin{array}{l}\text { Age groups: } \\
14-39 \text { years } \\
40-59 \text { years } \\
60 \text { years }+\end{array}$ & $\begin{array}{l}25.83 \\
20.55 \\
16.87\end{array}$ & $\begin{array}{l}4.16 \\
4.16 \\
2.94\end{array}$ & $\begin{array}{l}16.1 \\
20.2 \\
17.4\end{array}$ & $\begin{array}{l}40 \\
32 \\
26\end{array}$ & $\begin{array}{l}38 \\
37 \\
26\end{array}$ \\
\hline $\begin{array}{l}\text { Profession (head of household): } \\
\text { self-employed, leading position } \\
\text { civil servant, employee, skilled } \\
\text { worker } \\
\text { worker, without profession }\end{array}$ & $\begin{array}{r}11.27 \\
42.52 \\
9.47\end{array}$ & $\begin{array}{l}1.44 \\
7.96 \\
1.86\end{array}$ & $\begin{array}{l}12.8 \\
18.7 \\
19.6\end{array}$ & $\begin{array}{l}17 \\
68 \\
15\end{array}$ & $\begin{array}{l}13 \\
71 \\
17\end{array}$ \\
\hline $\begin{array}{l}\text { Education level: } \\
\text { elementary school } \\
\text { middle school } \\
\text { Gymnasium, university }\end{array}$ & $\begin{array}{l}32.86 \\
19.48 \\
10.91\end{array}$ & $\begin{array}{l}7.39 \\
2.97 \\
0.90\end{array}$ & $\begin{array}{r}22.5 \\
15.2 \\
8.3\end{array}$ & $\begin{array}{l}51 \\
31 \\
17\end{array}$ & $\begin{array}{r}66 \\
26 \\
8\end{array}$ \\
\hline
\end{tabular}

Source: AG Media-Analyse, (MA97-2), Printmedia.

This information on the economic status and the readership may reflect the extraordinary position held by the Bild-Zeitung but it cannot answer the question if the Bild is regarded as a prototypical leader or representative of what is called "tabloid journalism". For this reason and to gather first empirical evidence in answering this question, a small (non-representative) survey was conducted with students of the Johannes Gutenberg-University of Mainz in April of this year. 130 beginners in communication sciences or students of other faculties were asked among other things to write down within 1 minute 30 seconds their spontaneous associations regarding the phenomenon of "tabloid journalism." The question was explicitly not restricted to the print media. 48,5\% of the respondents had the immediate association of "BildZeitung." In other words, thinking about tabloid journalism nearly every second person at once came up with this newspaper which validates our assumption that the Bild can be taken as prototypical for this kind of journalism in Germany.

\section{Framing Analysis - a Useful Method to Detect Coverage Patterns in the Press}

Coming back to our first leading research question concerning the characteristics of tabloidised political coverage, we must ask now in which way the political discourse within the Bild is best to be described. How can prototypical patterns in content and language style be evaluated in a generalised way? According to Entman, the major task of determining textual meaning should be to identify and describe frames (1993, 57). "Media frames," Gitlin $(1980,7)$ wrote, "largely unspoken and unacknowledged, 
organise the world both for journalists who report it and, to an important degree, for us who rely on their reports." 13 years later, Entman explains framing in the following way: "To frame is to select some aspects of a perceived reality and make them more salient in a communicating text, in such a way as to promote a particular problem definition, causal interpretation, moral evaluation, and/or treatment recommendations for the item described. Typically frames diagnose, evaluate, and prescribe." $(1993,52)$.

News frames exist at two levels: as mentally stored principles for information processing and as characteristics of the news text. Examples of typical frames are the cold-war-frame and the horse-race-frame imposed on election campaigns. Frames can be detected by probing for particular words and visual images that consistently appear in a narrative transmitting specific meanings within or across media and time. Through repetition and reinforcing associations with each other the words and images that comprise the frame render one basic interpretation more readily discernible, comprehensible, and memorable than others.

Thus, we can conclude that "frames" combine a pragmatical, semantical and syntactical dimension, as they serve as internalised guides for information processing and as they convey thematically consonant meanings constructed from and embodied in the keywords, metaphors, concepts, symbols and other lexical or visual "bricks". On the one hand there are eventspecific frames, quickly developed ad hoc for entirely new breaking events like "theKAL-attack"-frame for the Soviet downing of a Korean Air Line Jet in contrast to "thetechnical-problem"-frame for US downing of an Iranian plane in major US newspapers and TV-channels (Entman 1991). There are, furthermore, frames for certain policy issues, like nuclear power, which may change over time. Gamson \& Modigliani (1989) distinguish three different frames for the development of attitudes against the nuclear power policy issue: the "progress"-frame, a "runaway"-frame and a "devil's-bargain"-frame.

In order to exactly work out the nature of certain frames in a specific type of news discourse it would normally be necessary to describe the news texts carefully by classifying framing devices and by analysing in depth the multilayered hierarchy of frame-supporting elements in the whole newstext (see Pan \& Kosicki 1993, or Hansen \& Murdock 1985). For our (exploratory) purposes, we will restrict the textual analysis to headlines, because "a headline is the most salient cue to activate certain semantically related concepts in reader's minds; it is thus the most powerful framing device" (van Dijk 1988, 59). Moreover, headlines usually serve as a summary of the thematic structure of a news story, and the whole rhetorical structure is already prepared in the headlines. The rhetorical structure of a news discourse describe the stylistic choices made by journalists in relation to their intended effects. Metaphors, exemplars, catch phrases, depictions, visual images or word games, language style, punctuation marks belong to this category, used by journalists preferably in the headlines to invoke images, underline salience of a point and increase vividness. Thus, headlines fulfil a keyfunction in framing analysis.

\section{Typical News Frames in the Political Coverage of the German Bild-Zeitung}

It is obviously true that the amount of articles concerning politics has considerably increased in the Bild-Zeitung since 1992 which is mainly due to a change of the editor in chief, ${ }^{2}$ but the place value assigned to political issues is still limited. This estimation, however, depends largely on the definition of political content. To differentiate between 
political or non-political information is not always an easy task because seemingly non-political issues like crimes or sexual deviance, sports or other "harmless" human interest stories certainly have a "political dimension" (nationalism, gender-stereotyping or inherent conservative social norms and values etc., see Sparks 1992). On the other hand, there is indeed also a manifest and very traditional political content, and as research on this type of content in the Bild-Zeitung has been restricted to certain policy issues (Küchenhoff 1972, Riedmiller 1988, Lepold 1998) but has not been analysed concerning typical news frames or overall consistent patterns in the political news discourse, we will stick first of all to a traditional, conservative understanding of political coverage.

In this sense Udo M. Krüger has defined the latter as combining "all contributions dealing with events, questions or problems lying in the sphere of public officials referring primarily to the community, the state, and the legislative or executive power. Politicians can but do not have to be the acting figures" $(1996,366)$. This definition represents the basis for the choice of items in the paper.

\section{Method}

For the purpose of an exploratory analysis of typical news frames in the German Bild-Zeitung, three months of the three last years with general elections have been chosen as study material (months 1, 5, 9 in 1987; 3, 7, 11 in 1990 and 2, 6, 12 in 1994) under the assumption that the place value of political coverage is higher in these years, increasing our chance of getting a better insight into the "political dimension" of the Bild. Furthermore, the distribution of the material within the years prevents an electioncampaign-bias. The analysis focused on the first two pages of the corresponding copies because the majority of political articles in the Bild-Zeitung — if present at all - are mainly concentrated on these two pages. In order to evaluate typical news frames every second headline has been noted, and the full list of headlines was examined for consistent, repetitive patterns in content and rhetorical style. It is true that this method is only a limited, non-representative one but it is regarded as a first step towards a more systematic analysis of political news framing strategies in the tabloids or other printmedia.

\section{Results}

The following frames representing stable and repetitive patterns of coverage were identified. They cover the vast majority of all headlines: $\square$ "Politicians-as-ordinarypeople"-frame, $\square$ "Politics-as-personal-confrontation-or-agreement"-frame, $\square$ "Womanpoliticians-as-typical-females"-frame, $\square$ “Power-block-vs.-the-people"-frame, $\square$ “Politicaleducation-and-service"-frame, $\square$ "Anti-communism"-frame. In the following each frame will be illustrated by its corresponding typical headline-representatives, and framing elements will be discussed.

"Politicians-as-ordinary-people"-frame. This frame is - in quantitative terms - by far the most dominant one. Taking into account that personalisation is one of the most characteristic trait of the tabloids in general (see Gripsrud 1992, 85) it is therefore no surprise that this holds true for political news treatment, too. But there is a revealing variety in the way in which personalisation is applied to the political news discourse. Three variations can be distinguished. 
1. "Politicians-as-vulnerable-human-beings:" 9/1/87 From PARTY CONFEREnCE Stage to THEATRE FOR OP - LADY CDU MP IN EMERGENCY DASH. 21/9/87 POISON! GORBACHEV GRAVELY ILL. 26/7/90 SCHMIDT - ANOTHER HEART ATTACK - IN INTENSIVE CARE. 16/11/90 SCHÄUBLE IN AGONY NO SLEEP. 4/6/94 KILLER BUG - MAD COW DISEASE - DOCTORS' SLEAZE - MINISTER'S STRESS - HOW DO YOU STAND IT, MR. SEEHOFER? 7/12/94 CHANCELLOR KOHL IN AGONY - WISDOM TOOTH PLAYING UP 15/12/94 Agony! Kohl - When WiLl they operate? This "subframe" is not restricted to politicians themselves but is activated for relatives and friends, too: 9/1/87 STRAUSS DAUGHTER ON INTRAVENOUS DRIP. 23/6/94 KOHL'S FRIEND HENNIG - 7 HOUR CANCER OP! 20/11/90 Ow! MRs. KOHL GETS IT IN THE NECK FROM PAPARAZZI. Through the use of exclamation marks and dramatising adjectives and depictions describing the consequences of an illness or an injury (agony, ow!) the reader is encouraged to take compassion, to suffer with the politicians who are thus presented as ordinary weak human beings undergoing illnesses, stress and caring for beloved persons.

2. "Politicians-in their-leisure-time"-frame: 19/1/87 SMILES IN THE SNOW - WHERE POLITICIANS GO TO STOKE UP ENERGY. 23/1/87 LAST HOURS BEFORE TV DUEL - RAU MEDITATES KOHL MASTICATES. 7/6/87 AMONG FRIENDS AND GRANDCHILDREN - BIRTHDAY PARTY AT THE HERZOGS. 8/11/90 Gotcha Gysi! CAUGHT AT 150 KM/H IN SPEED tRAP! 1/2/94 CLINTON AND KoHL: PASS -TA TIME AWAY IN LITTLE ITALY. 6/12/94 GEIßLER IN RADAR SPEED SNAP - DRIVING BAN. These headlines indicate that politicians are treated like other "normal" stars or prominent people. In a moderate paparazzi-like manner private activities (taking place in public) are unfolded. This subframe, too, tells the reader that politicians are people like you and me, they go on holiday, visit restaurants and - as speeding drivers - they are not infallible.

3. "One-of-us-image-promotion"-frame: Being a holder of public office in the age of mass media implies that such people have the talent of multi-media self-promotion. One reason for this could be that a "political character" can be sold more popularly than impersonal and abstract politics. Politicians are, therefore, in a dilemma: on the one hand they should radiate the impression of expertise to legitimise leadership, on the other hand they must show that they are trying to continue to be "one of us." To achieve the second goal some populist methods are often utilised, for example, kissing babies, shaking hands, wearing blue-collar clothes when visiting a factory etc.

20/1/87 Greens' Duet - Schily at PIANO, JoschKa ON DRUMs. 18/5/87 OsKar UP Front BulL's eYe PROMPt! 30/3/90 CheERs, Mr. PRESIDENT! (Weizsäcker in Lissabon drinking portwine.) 23/2/94 BILD ASKS CDU MP - HOW DOES FAMILY RATE IN YOUR BOOK? 8/6/94 MR. KOHL - WHAT'S YOUR RATING ON FRIENDSHIP IN POLITICS? The chosen headlines describe these "one-of-us"-strategies which are even supported by the tabloid in a twofold manner: first, by publishing interviews on personal questions and secondly by the use of first names only ("Joschka," "Oskar"). The use of first name only or nicknames to identify celebrities is a prominent language device of the tabloids, having the purpose of bringing the reader close to the individuals featured in the stories, to establish a sort of intimacy (Schaffer 1995, 31). Summing up, we may hypothesise that the news stories fitting into this first frame called "politicians-as-ordinary-people" are likely to encourage by their inherent familiarity and sometimes melo-dramatic aesthetics a para-social interactionist reception mode by the readers.

"Politics-as-personal-confrontation-or-agreement"-frame. According to this frame the political decision making process is presented as a battle or a co-operation between single leading politicians, thus, politics in a democracy is a game between persons and the political competition is reduced to a personalised contest of the elite. Besides, 
decisions or political results are due to the "heroic" activities and extraordinary dedication of single persons (see the verbal choice in the following headlines: clean sweep, take over, pull out): 27/1/87 KoHL's BaTtLE WITH StRAuß. CHANCELLOR'S CLEAN SWEEP. 8/5/87 Missiles - What Kohl, Genscher and Vogel want. 2/11/90 NeW federal states BLÜM FOR CLEAN SWEEP IN JOB CENTRES. 5/11/90 What BRANDT CAN ACHIEVE IN IRAK. 23/6/94 PARTY CONFERENCE APPLAUSE: SCHARPing PULLS SPD OUT OF DOLDRUMS. 28/6/94 FDP IN DiRE Straits - Can Kinkel go it alone? Must Genscher take over?

"Woman-politicians-as-typical-females"-frame. Politicians are obviously not all alike: they do not have the same access to the media, nor do they enjoy the same level and volume of media support and interest. One of the crucial distinctions which can be made is that of gender (Khan 1994, Ross 1995, Ross \& Sreberny-Mohammadi 1997). As a result of interviews with 22 Woman MPs Ross and Sreberny-Mohammadi summarise that leading on from a discussion of the power of the image in influencing political meanings and messages, most women politicians believed that their own outward appearance was the focus of considerably more media attention than for their male colleagues. In which way are women politicians treated in the Bild-Zeitung?

The following headline examples can be regarded as absolutely typical for a repetitive highly gender-stereotyping pattern: 2/5/87 WÖRNER'S PA: FIRST RECEPTION IN DatTeln. Mother Agnes wON SOldiers' HeARTS. 30/5/87 Two WOMEN IN EleCtion CAMPAign MagGie At billiard table, Honeybunch in Rome 14/3/90 Top Story - SeVEn top POWER POSITIONS IN GENTLE HANDS - 91 TO GO FOR WOMEN'S "CENTURY". 2/2/94 SHAMPOO, SET AND ...SACK! FDP LEADER IN SLEAZE OVER HAIRDRESSER'S BILL. WANTED TO BE SMART GIRL. 3/2/94 BRAVE BEAUTIES - 2 women presidents for Sarajevo. 15/12/94 Deportation stop for Curds. Home Sec tells SchnarRe “No whey, Miss Muffet, Get OfF My tufFet!" 21.12.94 A ReAl Christmas Cracker! LADY MINISTER IRONS GIFT-WRAP PAPER.

In these headlines typical female attributes are underlined: care-orientation, housewife qualities, beauty and tenderness. The attributes "beautiful and brave" (3/2/ 94) are illustrated in the news story with the information that the two women presidents are wearing only light splinter-proof vests over their breasts. In the issue of 14/3/90 seven women heads of state are sketched. The attribute "gentle" (or tender) is explained in the following way: "Big heart, little power" (Corazon Aquino), "Much passion, but less economic expertise" (Bro Harlem Brundtland), "against Ortega in the election campaign she acted like a Madonna - all in white..." (Violetta Chamoro). Another point is interesting: nicknames are very seldom used for politicians. In our present context nicknames for women politicians are used to diminish a person ("Honeybunch") or to insult a person ("Schnarre"). The full name of the Minister of Justice of that time is Sabine Leutheusser-Schnarrenberger. "Schnarre" means rattle which can be interpreted as an allusion to her way of speaking. The high degree of "personalisation" in the last three frames stands in a remarkable contrast to the "collective" accusation in the case of unpopular political decisions, leading us to a very typical tabloid frame in the political discourse.

"Power-bloc-vs.-people"-frame. Two semantically different subframes can be distinguished:

1. "Alienation"-frame: This frame tells the reader that those in power have withdrawn from the people, but the people have a clearer insight into the political "reality". 27/5/87 DivorCE! HUSBANDS RIPPED OFF BY GOVERNMENT! 31/7/90 GDR GOVERNMENT - HOW THEY ARE WASTING OUR MONEY. 11/2/94 HeY, YOU UP THERE! KNOW WHAT IT'S LIKE DOWN 
HERE? 19/2/94 19 Mio GERMANS WANT to KNOW: ARE OUR PENSIONS SAFE? 22/2/94 BiLD OPINION

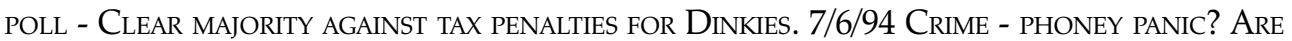
YOU OUt OF THIS WORLD, Minister? (Continued on page 2) Quote by Judicial Senator IN Bremen: "Old ladies are at lowest objective risk as regards Crime". Some talk to Bild ABOUT THEIR EXPERIENCES. 25/6/94 14.000 MARK PAY DEAL - TOP "MARKS" FOR ALL MP's?

The gap between the power-bloc and the people is expressed through personal pronouns like "you on top", "we/our", whereby "we" is not only reserved for the population as a whole, but also for parts of the public like men (27/5/87), old ladies (7/ 6/94), or pensioners (19/2/94) who represent at the same time the typical reader of the paper. The Bild-Zeitung does not make any secret of its role as "speaker" for the people, on the contrary, the paper regards itself as a lawyer, as a critic and as a supervisor of the powerful ("Bild opinion poll" 22/2/94, old ladies talk to Bild... 7/6/94).

2. "Indignation-and-appeal"-frame: 21/5/87 AIDS - NEW BLOW - COMPULSORY TEST FOR all Germans? 31/3/90 GDR Politicians - When will they Stand trial? 6/2/94 Outrage OVER BLOODBATH IN SARAJEWO - BOMB THE MURDERERS TO BITS! 1/6/94 OUtRAGE OVER NEW CRIME ReCord - Make Germany a SAFe Place to Live again! 28/12/94 Wot? 10 more years of SOLIDARITY TRANSFER TAX? THEY MUST BE JOKING! In the quality papers definitions, statements or comments on a situation like those cited above are normally made in quotation marks. Therefore, it is perfectly clear who the statements and definitions belong to. "MAKE Germany a SAFE PLACE TO LIVE AGAin!" turns out to be the voice of the paper speaking representatively for millions of readers. In the qualities it is clearly indicated through the use of quotation marks, that this is not necessarily the definition of the situation, but rather $a$ definition, made by a person or a group of people. Conversely, the absence of distancing quotation marks here makes their definition of the situation appear both natural and definitive. The lack of quotation marks also reproduces the characteristic populist mode of address by inviting the reader to regard the papers view as entirely consonant with the opinions quoted in the headlines.

"Political-education-and-advice"-frame. 23/1/87 THE TWELVE MAIN QUESTIONS ABOUT THE ELECTION. 30/1/87 CRISIS MANAGEMENT - WHO'S IN IT AND HOW IT WORKS. 18/9/90 KNOCK, KNOCK... What's IN THE NEW POST OFFICE PARCEL FOR Us? 16/11/90 NeW INCOME tAX CARDS WHAT YOU've GOT tO WATCH. 16/6/94 BILD PHONE-IN - RESEARCH WEEK. CAN I STILl EAT BEEF, MINISTER? 3/12/94 SOLIDARITY TRANSFER TAX SHOCK INDEX - HOW MUCH YOU PAY AND WHAT YOU'RE LEFT WITH. Within this frame, political facts or circumstances are explained on an elementary level, clear behavioural advice is given in reaction to political decisions of limited scope.

In a complex consumer and welfare society, the paper sets out to act as a helper and advisor for the average man and woman. On a syntactical level this frame is represented by explicit questions in the headlines, giving the reader two impressions: first, that it is not shameful to ask these (elementary) questions and second, that the Bild always has an answer to them. The paper provides assistance in the whole range of activities connected to the everyday roles of consumers, clients and private persons. Service journalism frames seem to be a general feature of the tabloids in other European countries, too, as Martin Eide explains for the Norvegian tabloids. According to him "this information service can be seen as a device to build an alliance - to make a contract - with the reader. When such contracts are no longer provided through traditional genres - such as news reports - the daily service pages do the job. They address a lifeworld where information does matter for the reader, not a system world 
where the readers' possibilities for action are limited. This is 'news-you-can-use' - the newspaper becomes a 'use-paper'" (Eide 1997, 177).

"Anti-communism"-frame. 25/9/87 RuSSIAN NUCLEAR BOMBER OVER BRAUNSCHWEIG. 23/ 3/90 Lithuania - Soviet tanKS ROll IN. 24/3/90 People Of the WORLD, SAVE Lithuania! 1/2/94 Russian Hitler whips up Serbians. 5/2/94 "Red BREAD" For SPD election CAMPAign - Aid FROM MOSCOW? 29/6/94 PDS: HOW MANY RED WOLVES IN SHEEP'S CLOTHING? 24/12/94 GROSNY - RUSSIANS BLITZ WOMEN AND CHILDREN. (16/2/94 RUSSIAN CROWS MAKE MEAL OF GERMAN SONG BIRDS!) It is astonishing that this frame has apparently survived the end of the ColdWar. The Bild still talks about the "Russian danger" evoking collective fears by using the corresponding symbols and metaphors e. g. atomic bombs, bombardment of women and children, tanks, Russian-Hitler, etc. The dangerous ghost of communism is evoked by using designators like "red wolves," which holds particularly true for the PDS, the successor party of the former SED in the GDR. Although non-political in the traditional sense, the last headline example shows that human interest stories can equally be framed. One explanation for the use of the frame is the fact that a strong anti-communist attitude was one of the four leading principles of the publisher Axel Springer. According to the Bild publishing office these principles which have always been regarded as unspoken editorial statutes are accepted as working guide-lines even today. ${ }^{3}$

\section{Missing Frames and a Glance Abroad}

The "Sexual-scandal"-frame. Given the nature and the thematic and structural strategies of the tabloids, it is astonishing that one frame is missing: the "politiciansand-their-sexual-immoralities"-frame. Sexual scandals of prominent people, the combination of sex and crime, sexual or erotic allusions normally play an important role in the tabloid press - it is taken for granted that this holds true for Bild - and one would have expected that politicians as prominent people would not be exempted from it. The only examples for the a. $\mathrm{m}$. frame in our material were the following: $22 /$ 5/87 Scheel: illegitimate SON tURNS UP OUT OF THE BLUE. (German ex-president) 9/2/94

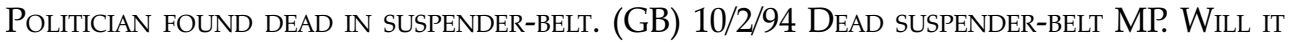
BRING THE GOVERNMENT DOWN? (GB) 17/2/94 OOPS! HEAD OF STATE CAUGHT WITH LADY WITH HER PANTS DOWN! (Brazil) 1/6/94 JUDGEMENT DAY FOR MINISTER - SEX WITH JUDGE'S WIFE AND HER TWO DAUGHTERS. (GB) 10/12/94 BONN POLITICIAN CONFESSES: “I'M GAY, I WANT TO MARRY A MAN." (unknown back-bencher). According to these headlines the frame does exist but preferably for foreign politicians. "Immoral" sexual behaviour of German politicians is - at best - published only when they are no longer in office or completely unknown. How can we explain this striking discretion compared to the tabloid press in GB e. g.? Why can this frame be omitted as an extreme form of tabloidised political coverage in the German press? Although Germany's protection of the freedom of the press is one of the most stringent in Europe (Dewall 1997, 56) it is subject to some important limitations. The rights to reputation, personal honour and privacy are strongly protected by a collection of both civil and criminal law.

The 14th chapter of the Criminal Code contains rules concerning defamation and it specifies three basic violations of a person's honour. The first violation is insult, furthermore, there are two kinds of libel. The German terms are "Üble Nachrede" CC $\$ 186$ and "Verleumdung" CC \$187. Public figures must accept a greater degree of criticism about their public actions than private persons. It is true that, therefore, politicians are 
legally seen as "persons of contemporary historical significance" and that their activities and their behaviour are regarded as being of a strong public interest, but "persons of political life" enjoy an even stronger protection against all sorts of libel. This rule was introduced in 1951 in $\$ 187 \mathrm{a}$ of the Criminal Code and has been explained by the fact that such persons are especially exposed to the public and, therefore, more vulnerable than others (Löffler \& Ricker 1994, 388; for relevant decisions see Nolte 1990, 234-258).

The individual's protection from invasion of privacy in German Civil Law is generally referred to as the "general rights of personality ("Allgemeines Persönlichkeitsrecht"), mainly regulated by the Civil Code. A clear distinction is made for three protected personal spheres (in the range of growing protection): the individual sphere, the private sphere and the intimate sphere. Sexual behaviour clearly concerns the latter. In general, coverage of this sphere is illegal.

In the 90's the relationship between the media and politicians became very tense. This was because of the media's reporting of a number of "scandals" involving political figures above all by the newsmagazine Der Spiegel. Several politicians reacted negatively and criticised the media for fuelling up public contempt for politics and politicians. Politicians also felt that the media were intruding into their private spheres and that they were subject to unfair or even humiliating reporting. The point here is that none of these scandal-reports (about corruption, lavish salaries and pensions, misuse of state funds...) included details of sexual preferences or "immoral" sexual behaviour. Therefore, the press defended itself against the criticism. The German press, it was argued, was very discreet when it came to the private lives of politicians. There was common agreement that so long as their personal lives did not interfere with politics or their public office, politicians could do what they wanted. Siegfried Weischenberg, professor of journalism, strongly supports this point of view: "At all events the private lives of our heroes from the world of politics (...) are safe from the press. From this point of view German journalists give less cause for concern. The German Press Council can rest reassured". $(1995,22)$.

In contrast to Germany, there exists no specific privacy legislation in the UK, a fact that was obviously the subject of much discussion in the 90's. One of the cases under discussion of that time was the fact that the leader of the Liberal Democrats, Paddy Ashdown, was forced to confess to an affair with his secretary: "It's Paddy Pantsdown" titled the Sun on its front-page on the 6th February, 1992. The case led to renewed calls for privacy legislation from politicians, and Lord McGregor, then chairman of the Press Complaints Commission, made an appeal for restraint:

"If, as many people fear, newspapers regard it as their proper function to turn themselves into Kinsey Reports on politicians, then they will greatly increase the likelihood that, at the end of the Commission's probation period, parliament will both pass a law of privacy and establish a statutory commission with legal sanctions". (quoted in Snoddy 1993, 207). The government decided against the introduction of a privacy law. ${ }^{4}$ To sum up, this lack of an institutionalised law of privacy may be one reason for the differences between the UK and Germany concerning the different degree of invasion of the private lives of politicians. But it is certainly not the only one.

The German Bild-Zeitung holds an absolute monopoly in the national tabloids market whereas in the UK 12 national tabloids heavily compete with each other, fighting for their readers every day. A lowering of standards, a more reluctant attitude regarding ethical norms and a growing sensationalism might be the logical consequences. ${ }^{5}$ Although there are voices like that of David Hellier of the Sunday Express who feel that 
there is an obsession with the sex lives of politicians and that the press at large has been so influenced by the tabloid press that such stories are now common currency in all sections of the press which would have been impossible a few years ago, others argue that the politicians themselves and their hypocritical behaviour is the reason for journalists to activate the sexual-scandal-frame. (see Dewall 1997, 212). It is argued that many politicians officially stand for family values but practice a rather different private morality (take e. g. the Conservatives' "Back to Basics Campaign" in 1994), in these cases of a double standard of morals there exists a legitimate public interest in such stories. Coming back to the situation in Germany and the widespread taboo concerning sex and politicians and following this line of argumentation, the journalistic discretion, therefore, could be the simple reaction to the fact that German politicians do not propagate the moral standards that they themselves do not meet, thus, giving less opportunities for such publications.

"The-'vote-for'/'vote-against"'-frame. In the case of this potential frame, too, there is a striking difference between the two countries. All along, the British tabloids have shown an affinity to a special political party supporting it in the general elections (Seymour-Ure 1991, 196f.). A culmination point of this "campaign-journalism" was obviously reached in the election campaign of 1992. Even today, this campaign is entitled with the running slogan "It's the Sun wot won it" (see Linton 1996). By means of direct appeals, the outlining of horror-scenes, making fools of politicians and other highly dramatising and emotionalising lexical and visual components on the front pages, readers are stirred up: In the final week before the election in 1992 the Sun published the 9-page story "Nightmare on Kinnock-Street", the Daily Express writes on the front page: "You, the British people, have achieved great things for yourselves and for your country. DON'T THROW IT ALL AWAY. (8/4/92), whereas the Daily Mirror answered: "The time is now: VOTE LABOUR" (9/4/92).

It is true that in both countries the publishers play an important role in the establishment of political guidelines. In the case of The Sun it was Rupert Murdoch who switched it to the Tory camp and nowadays to Labour, in the case of the BildZeitung it was above all Axel Springer who imposed his political ideas on his journalists, but such an aggressive campaign journalism as in GB cannot be counted among the extreme forms of tabloidised political coverage in Germany. Springer's attitude is reflected in the following statement made by the editor in chief in the years 1992 to 1997, Claus Larass: "Loyalty to the state is a civic duty. This does not mean loyalty to the government, which is different. Each paper should have a positive idea of the country in which it is published. A journalist thinking in party-political categories is out of place". (Koch \& Hartmann 1996, 115). The Logo on the front page gets across to the reader every day that Bild is "independent and unbiased," although there is no doubt that the Bild has a nationalistic and conservative attitude. Nevertheless, at the end of an analysis of Bild-commentaries, Klingemann \& Klingemann resume in accordance with an older study: "The results contradict the idea that the Bild directly and massively supports the interests of the capitalistic lobby" $(1983,258)$. Moreover, the Bild-Zeitung is very anxious not to loose its image of political independence. This could be observed in recent times during the discussion about the political editor in chief, Kai Diekmann, who made a bad impression by singing the praises on chancellor Kohl and his "impressive personality" (see Ott 1997). Meanwhile, Diekmann has disappeared from the press sheet. 


\section{Conclusion}

This paper is to be seen as a first attempt in the development of indicators for "tabloidised" political coverage in the (German) press. The framing-concept has turned out to be a useful method to discover specific issue-independent coverage patterns in the political news discourse of tabloid papers. The qualitative, exploratory analysis of headlines of the Bild-Zeitung, which can be characterised as particularly powerful framing devices, has revealed six consistent and repetitive frames. Under the validated assumption that the Bild is to be seen as the most important representative of tabloid journalism in Germany these frames can be regarded as prototypical. At least four of them ("politicians-as-ordinary-people," "politics-as-personal-confrontation," "politicaleducation-and-advice" and "the-power-bloc-vs.-the-people") are able to explain the popularity of this tabloid assuming that it is read because of its political content, too. On the one hand, political coverage in the Bild can be characterised by the general prevailing melodramatic framework of the popular press because of its emphasis on drama, conflict, personalities and emotions. On the other hand, readers are offered guidance in understanding a complex political world as journalists are asking and answering elementary political questions touching on the everyday political reality of ordinary people. Moreover, the cultivated conception of the paper is that the journalist is on the side of its readers, pushing the politicians to come up with clear arguments and effective solutions. Thus, tabloidised political coverage can be conceived according to Gripsrud (1992) — as a popular protest against an abstract and theoretical under-standing of society.

It is possible that due to the limited quantity of our study material other prototypical frames of the political news discourse have inevitably been overlooked (e. g. those indicating xenophobic attitudes and national stereotypes in the coverage of foreign politics). Therefore, a more systematic framing and content analysis is needed in order to validate the salience and consistence of the frames. As a next step, tabloidisation in the political coverage of other printmedia in Germany can be detected by probing for the amount of prototypical tabloid frames. A longitudinal content-analytical design would enable us to discover a tabloidisation process as a process of the growing application of typical tabloid frames. For an international comparison of a tabloidisation process in the press of different countries it must be taken into consideration that there do exist major differences in the extremity of the tabloid frames (see for the Scandinavian countries Eide 1997, for the situation in Spain see Höber 1997, for GB see chapter "Missing frames" in this paper). To understand the phenomenon of tabloidisation a closer and more systematic look at the very nature of tabloid journalism is advisable.

\section{Notes:}

* The author would like to thank Bernd Spanier for the congenial translation of the headlines.

1. Since 1996 the Bild has been available on-line and according to the CD-Rom information of the publishing house 400.000 user look at some 3 million on-line-pages per month.

2. In 1992 Claus Larass became the successor of the former editor in chief Hans-Hermann Tiedje who has made a stand for smashing tabloid journalism. Larass followed a change of course by introducing a mixed page 2 with political, economic and service topics (see interview with Larass in Koch \& Hartmann 1996). 
3. Telephone call with Frank Mahlberg, Bild publishing office, Hamburg, 9th May, 1998. The other principles are: commitment for the German reunification, reconciliation with the Jews and support for a social market economy.

4. Hereto, according to Dewall (1997, 196-212), three main lines of argumentation can be distinguished: First of all, it was argued that the Press Complaints Commission was sufficiently effective and that this made the introduction of privacy unnecessary. Secondly, it was argued that the government was not able to define privacy, thus making it impossible to draft legislation. The third argument was that the government did not wish to make enemies of the press.

5. For other essential differences between the British and German journalistic cultures see Esser 1997.

\section{References:}

AG Media-Analyse e. V. 1997. MA 97-2, Pressemedien. (CD-ROM). Frankfurt: Media-Micro-Census $\mathrm{GmbH}$.

Bruns, Thomas and Frank Marcinkowski. 1997. Politische Information im Fernsehen. Eine Längsschnittstudie. Opladen: Leske + Budrich.

Dewall, Gustaf von. 1997. Press Ethics: Regulation and Editorial Practice. Düsseldorf: EIM Public. Dpt.

Ehmig, Simone C. 1991. Parteilichkeit oder Politikverdrossenheit? Die Darstellung von Motiven und Emotionen deutscher Politiker im "Spiegel". Publizistik 36, 183-200.

Eide, Martin. 1997. A New Kind of Newspaper? Understanding a Popularization Process. Media, Culture \& Society 19, 173-182.

Entman, Robert M. 1991. Framing US Coverage of International News: Contrasts in Narratives of the KAL and Iran Air Incidents. Journal of Communication 41, 4, 6-27.

Entman, Robert M. 1993. Framing: Toward Clarification of a Fractured Paradigm. Journal of Communication 43, 4, 51-58.

Esser, Frank. 1997. Journalistische Kultur in Grossbritannien und Deutschland. Eine Analyse aus vergleichender Perspektive. In M. Machill (ed.), Journalistische Kultur. Rahmenbedingungen im internationalen Vergleich, 111-136. Opladen: Westdt. Verl.

Gamson, William A. and Andre Modigliani. 1989. Media Discourse and Public Opinion on Nuclear Power: A Constructionist Approach. American Journal of Sociology 95, 1, 1-37.

Gitlin, Todd. 1980. The Whole World is Watching: Mass Media in the Making and Unmaking of the New Left. Berkeley CA: University of California Press.

Gripsrud, Jostein. 1992. The Aesthetics and Politics of Melodrama. In P. Dahlgren and C. Sparks (eds.), Journalism and Popular Culture, 84-95. London: Sage.

Hansen, Anders and Graham Murdock. 1985. Constructing the Crowd: Populist Discourse and Press Presentation. In V. Mosco and J. Wasko (eds.), Popular Culture and Media Events, 227-257. Norwood, N.J: Ablex.

Hesse, Kurt R. 1994. Das politische Informationsangebot im Hörfunk: Ergebnisse von Programminhaltsanalysen. In O. Jarren (ed.), Politische Kommunikation in Hörfunk und Fernsehen, 149-156. Opladen: Westdt. Verl.

Höber, Birgit. 1997. Boulevardjournalismus in Spanien. In M. Machill (ed.), Journalistische Kultur, 211222. Opladen: Westdt. Verl.

IVW. 1998. Auflagenliste 1/98. Bonn: Informationsgemeinschaft zur Feststellung der Verbreitung von Werbeträgern e.V (IVW).

Khan, K. F. 1994. The Distorted Mirror: Press Coverage of Women Candidates for Statewide Office. Journal of Politics 56, 1, 153-174.

Klingemann, Hans-Dieter und Ute Klingemann. 1983. Bild im Urteil der Bevölkerung. Publizistik 28, 239-259.

Koch, Martin and Axel Hartmann. 1996. Blutrünstiges ist nicht mehr so wichtig. werben \& verkaufen $48,114-115$.

Kreutzfeld, Nina and Verena Schmidt. 1996. Auswahlbibliographie: Politische Öffentlichkeit und massenmediale Politikvermittlung. In O. Jarren, H. Schatz and H. Wessler (eds.), Medien und politischer Prozess, 289-314. Opladen Westdt. Verl. 
Krüger, Udo Michael. 1996. Boulevardisierung der Information im Privatfernsehen. Media Perspektiven 7, 362-374.

Küchenhoff, Erich. 1972. Bild-Verfälschungen. Analyse der Berichterstattung der Bild-Zeitung über Arbeitskämpfe, Gewerkschaftspolitik, Mieten, Sozialpolitik. Frankfurt/M.: Europ. Verlagsanstalt. Lepold, Oliver. 1998. Der Euro in Bild. (Thesis). Hannover: Hochschule für Musik und Theater. Linton, Martin. 1996. It was the Sun wot won it. New Statesman \& Society, March 2, 20-21.

Löffler, Martin and Reinhart Ricker. 1994. Handbuch des Presserechts. München: Beck.

Marcinkowski, Frank. 1996. Politikvermittlung durch das Fernsehen. In O. Jarren, H. Schatz and H. Wessler (eds.), Medien und Politischer Prozess, 201-212. Opladen: Westdt. Verl.

Nolte, Georg. 1990. Beleidigungsschutz in der freiheitlichen Demokratie. Berlin: Springer.

Ott, Klaus. 1997. Ins Ausland abgeschoben. Warum der Politikchef der Bild, Kai Diekmann, das Blatt verlassen soll. Süddeutsche Zeitung, July 1, 18.

Pan, Zhongdang and Gerald M. Kosicki. 1993. Framing Analysis: An Approach to News Discourse. Political Communication 10, 55-75.

Pfetsch, Barbara. 1994. Politische Fernsehwelten: Die Politikberichterstattung in privaten und öffentlich-rechtlichen Sendern. In O. Jarren (ed.), Politische Kommunikation in Hörfunk und Fernsehen, 111-122. Opladen: Westdt. Verl.

Riedmiller, Thomas. 1988. Arbeitslosigkeit als Thema der Bild-Zeitung. Tübingen: Vereinigung f. Volkskunde.

Ross, Karen. 1995. Gender and Party Politics: How the Press Reported the Labour Leadership Campaign 1994. Media, Culture \& Society 17, 3, 499-509.

Ross, Karen and Annabelle Sreberny-Mohammadi. 1997. Playing House-gender, Politics and the News Media in Britain. Media, Culture \& Society 19, 1, 101-109.

Schaffer, Deborah. 1995. Shocking Secrets Revealed! The Language of Tabloid Headlines. Et cetera $52,1,27-46$.

Schatz, Heribert. 1989. Hochtechnologiepolitik und Massenkommunikation. Veränderungen in den Grundlagen politischer Kommunikation. In M. Kaase and W. Schulz (eds.), Massenkommunikation. 118-134. Opladen: Westdt. Verl.

Schulz, Winfried. 1997. Politische Kommunikation. Opladen: Westdt. Verl.

Seymour-Ure, Colin. 1991. The British Press and Broadcasting since 1945. Oxford: Basil Blackwell.

Snoddy, Raymond. 1993. The Good, the Bad and the Unacceptable. London: Faber and Faber.

Sontheimer, Michael. 1995, January. Ein hartes Blatt. Journalismus an der Grenze der Geschmacklosigkeit. Spiege/ Special (Die Journalisten) 1, 38-43.

Sparks, Colin. 1992. Popular Journalism: Theories and Practice. In P. Dahlgren and C. Sparks (eds.), Journalism and Popular Culture, 24-45. London: Sage.

Stamm, Willy, ed. 1997. Presse- und Medienhandbuch Stamm 1997. Essen: Stamm Verl.

van Dijk, Teun A. 1988. News as Discourse. Hillsdale, N.J.: Erlbaum.

Weischenberg, Siegfried. 1995, January. Vom Leithammel und den Angsthasen. Legenden um den Journalismus in Deutschland. Spiege/ Special (Die Journalisten) 1, 20-22.

Weischenberg, Siegfried, Martin Löffelholz, and Armin Scholl. 1994. Merkmale und Einstellungen von Journalisten. Media Perspektiven 4, 154-167. 